\title{
Reviewing history in apocalyptic literature as ideological strategy
}

\author{
P M Venter \\ Department of Old Testament Science \\ University of Pretoria
}

\begin{abstract}
Reviews of history are ideological constructions. This article investigates historical reviews in the apocalyptic literature of Daniel and Ethiopic Enoch. In Daniel 2 a fourfold scheme of successive kingdoms/empires/eras is used to persuade the hearers that their political trials will come to an end. In Daniel 7 a theology of history is formulated in terms of animal symbols and four consecutive eras. This review is used to proclaim God's total sovereignty over kings and kingdoms. The faithful can only wait with patience for God to bring history to its finalisation. In Enoch's Apocalypse of the Weeks a historical review of humanity's history is used to advocate the eschatological hope of the annihilation of sin and eternal vindication of righteousness. Summaries of history in the form of the traditional biblical history (1 Enoch 85-89) and an Animal Vision (1 Enoch 8990) of seventy periods is used to appraise contemporary politicalmilitary events and advocate the reader's participation in these actions as eschatological liberating events.
\end{abstract}

\section{INTRODUCTION}

Colleague Andries Breytenbach, to whom this article is dedicated, followed Jeismann (1985:13-14) in his view that history writing always has an "identitätstiftende Funktion", "Legitimierungsfunktion", and an

"Orientierungsfunktion". Breytenbach applied these principles of identity forming, legitimating and orientation to the process of canonisation. He saw it as a process which took place in the context of "historical consciousness, the contextuality and intertextuality of texts, master narratives and contra narratives and the community of interest" in forming a canon (my translation; Breytenbach 1997:1168).

Documents themselves are "ideological records" (Boccaccini 2002:29). They serve as ideological expressions of particular religious viewpoints. When historical reviews are found in these literary documents they reflect the author(s)'s view of the past and contribute to the author's ideology expressed 
in the document. It forms part of his/their general ideological construction (cf Baumgarten 2000:2-3). It is a crucial component of his/their ideological foundations (cf Baumgarten 2000:9). These reviews are therefore constructed from an ideological perspective that identifies, substantiates and affirms the ideas of the author/movement.

Jewish national, sectarian and universal narrative accounts of histories can be branded as a genre in the Bible and Bible related literature. Historical reviews that recount the history is found at several places in the Old Testament. The oldest and longest appraisal occurs in Deuteronomy 32:1-43. Other instances of historical summaries are found in Psalms 78, 105, 106, 135, 136, Ezra 9, Nehemiah 9:5b-37, Ezekiel 16 and 20, Daniel 2:1-49, 7:1-28, 9:4-19 and $11: 14$. It is also found in related literature like Ecclesiasticus 44-49; the Animal Vision (1 Enoch 89:59-90:19); Apocalypse of the Week (1 Enoch 93:1-10); Tobit 14:4-7; Cairo Damascus Document 1:3-12, 2:14-4:12, 5:20-6:11; and Jubilees 1:7-18 and 23:13-21.

These historical reviews are important in that they enable us to reconstruct some of the authors' ideological foundations. Nickelsburg (2001:398-400) interprets Daniel 2, 7, 9 and 11:14, the Animal Vision and the Apocalypse of the Weeks as traditions coming from a religious awakening in the Hellenistic period. He also differentiates between the traditional historical reviews of history and these found in this mostly apocalyptic literature. Nickelsburg (2001:32) calls them the "revealed summary of history." This study focuses on these "revealed summaries" in Daniel and Enoch aiming at contributing to our knowledge of the ideologies of the second century BCE, especially those related to apocalypticism.

\section{HISTORICAL REVIEWS IN DANIEL}

\subsection{Daniel 2}

In Daniel 2:1-49 a historical review is presented in the form of a dream (2:31$35)$ and its interpretation (2:37-45). The second chapter of Daniel is a narrative about king Nebuchadnezzar who had a dream and expected from his subjects to tell him what he dreamt and to give its meaning. The basic theme of this narrative is that of a king who looked for a divine revelation and found it (cf Venter 1993:1015-1019).

To understand the ideology of the historical review it has to be studied in the context of the narrative. The narrative consists of 8 scenes presented in 3 episodes. In the narrative text two poems are embedded (2:20b-23 and $2: 47 \mathrm{~b}-\mathrm{e})$. They contribute to the theme(s) of the narrative. In scenes 6 (2:29$35)$ and 7 (2:36-45) the narrator presents the main character, Daniel, as narrator presenting the contents of the dream and its meaning. Through this 
technique not only a "narrative within a narrative" (Fewell 1991:31) is created, but also a second level of meaning is added to the basic theme of the story in Daniel 2. On the basic theme of a king looking for a revelation and finding it, the second theme is superimposed of God who has the power to install and dispose of kings. The revelation received by the king is expounded by Daniel's narrative of the contents of the revelatory dream and its meaning. Daniel's "statue narrative" (2:31-35) presents a story about an image made of different metals and its eventual destruction when a rock struck it. When this statue narrative is repeated in 2:37-45 the same order is followed but the meaning of the dream is added this time. These two narratives form a parallel pair framed by the phrase "what will occur after this." The phrase occurs at the beginning of the first one (2:29) and at the conclusion of the second one (2:45). Both the statue narrative and the narrative on the interpretation of the statue resolve the basic plot of the king looking for a revelation, and simultaneously adds a second level of meaning to the narrative, that is the future will illustrate God's power to instate and demolish successive kingdoms. This theme echoes the central strophe (2:21a-b) of the first embedded poem in the larger narrative of Daniel 2 (cf Venter 1993:1011-1014, 1019). Both highlight the message of God's power over nations and point this out as the central theme of the narrative of Daniel 2.

The narrative's ideology on the nations as subjected to God's power is depicted in two ways. Firstly the nations are pictured as kingdoms symbolised by different metals. The large statue in the dream (2:31-36) made of gold, silver, bronze and a mixture of iron and clay is explicitly linked to four kingdoms in the interpretation narrative (2:36-45). Secondly, these kingdoms are linked to each other as four successive kingdoms. They indicate, "what will occur after this" (Dn 2:29; 2:45). A second kingdom will follow after Nebuchadnezzar's kingdom, then a third and a fourth (Dn 2:39-40). These kingdoms represent a sequential history that will end when God sends a stone hewn from a mountain to destroy the whole statue. Take note that not only the last kingdom of iron and clay, but the whole image of gold, silver, bronze, iron and clay will be shattered (Dn 2:45). Although they are successive these kingdoms form one statue. The destroying kingdom represented by the rock from the mountain will, however, never be destroyed and will endure forever (Dn 2:44).

To symbolise kingdoms or eras with metals was well known in the ancient world. The Greek Hesiod in his Works and Days 109-201 of ca. 800 $\mathrm{BCE}$, symbolised eras in human history with gold, silver, bronze and iron (cf Miller 1994:93). Later on the Roman Ovid symbolised the four ages of humankind as a process of degeneration with four metals in his 


\section{Reviewing history in apocalyptic literature as ideological strategy}

Metamorphosis I, 89-150 (cf Lacocque 1979:48). Baldwin (1978: 97-98), however, indicates two obvious differences between Daniel and the other reviews of history: Hesiod had no interest in the future while Daniel's scheme is presented as a glimpse in the future. Different to the others who present world periods or succeeding conditions of humanity Daniel presents historical periods of imperial dominion. In the second explicative statue narrative Nebuchadnezzar's kingdom is explicitly linked to the statue's head of gold (2:38). The other three kingdoms are not linked to any specific realm. They are only said to be successive to that of Nebuchadnezzar's and to be inferior to his kingdom. They are arranged in terms of the dwindling qualities of the statue's materials inferior to the previous. As the other kingdoms are unspecified in the narrative they cannot be linked with certainty to any known historical political entity. It is after all not even sure whether these metals refer to successive Babylonian realms (cf Goldingay 1989:51), or to different world empires, or even to mere eras in the history of that time.

The periodisation of history into a sequence of kingdoms/empires/eras in Daniel 2 is also found in other literature. The motif of four kingdoms given in a political oracle also occurs in Sibylline Oracle 4 and the Bahman Yast (cf Collins 1984:50). In this case the author(s) of Daniel utilised this four-scheme review of history to proclaim that God has power over all of the consecutive kingdoms and can bring them to an end. The declaration of God's eternal reign is enhanced by linking the kingdoms of this scheme to the known kingdoms/empires/eras in the world. In this case only Nebuchadnezzar's period in office can be recognized with certainty.

Scholars differ as to the other kingdoms. Generally two schools are found in identifying the other kingdoms (cf Koch 1980:182-205). The traditional school identified the fourth political entity in Daniel 2 and 7 with the empire of Rome. According to this school of thought the historic scheme of successive empires used by Daniel was Assyria, Media/Babylon, Persia, Greece, and Rome. One of the implications of this theory is that the historical scheme used in Daniel is understood to be prophetical of the time after the book was written.

Since the "Makkabäerthese" (Koch 1980:185) arose in the $18^{\text {th }}$ century the Four Empire Scheme was linked to the Greek-Macedonian empire of the Diadochi in Syria and Egypt. Daniel 2 and 7 read in conjunction with the contents of Daniel 10-12 mirror the reign of Antiochus Epiphanes. With his edict in 168/7 BCE he desecrated the temple in Jerusalem and caused the crisis reflected in the book of Daniel. The formal scheme of four empires according to this school is Assyria, Babylon, Media-Persia, and Greece. 
Putting the author(s) of Daniel in the time just before the revolt of Judas Maccabeus scholars from this school, such as LaCocque (1979:36) and Collins (1993:147), link the historical scheme to the world empires from the fourth to second century BCE (Babylon-Greece). Hartman and Di Lella (1978:148) see the fourth kingdom as the last kingdom in the series of Babylon, Media, Persia and Greece. The importance of the fourth kingdom is stressed in the narrative by the longer length in the narrative time dedicated to this kingdom (2:40-43) compared to the other three, by its description in terms of iron (repeated 9 times) and clay (repeated 5 times), and by the explicit narration of the dramatic regression in the strength of this kingdom (cf Collins 1993:170). This indicates that the intended hearers of the narrative of Daniel 2 were rather people living during the fourth kingdom than the time of Nebuchadnezzar who had no real interest in that kingdom. Collins (1993:170) sees in the deterioration from legs of iron to feet and toes partly of iron and partly of clay a reference to Alexander the Great and the division of his empire in to four sections on his death in $322 \mathrm{BCE}$. According to Hartman and Di Lella (1978:149) and Grabbe (1992:283) the mixing of iron and clay refers to several diplomatic intermarriages between the Hellenistic empires of the Ptolemeans and the Seleucids.

To apply the fourfold scheme to either the sequence of AssyriaBabylon-Persia-Greece-Rome or Assyria-Babylon-Media-Persia-Greece takes extraordinary resourcefulness. Both have hermeneutical implications for understanding the book. Both try to link the contents of the book in a positivistic way to known history to use that known history as a heuristic tool to understand the book. They share the idea that the truth of its message depends on the verified historical scheme to which it can be linked. In his thesis Van Deventer (2002:158-159) indicates that the differences in interpretation of the kingdoms to which the scheme refers do not alter the persuasive effect presented by the dream and its interpretation. For Collins (1984:53) the political contents of the dream appear "to be almost incidental to the message of the chapter." To whichever historical persons and kingdoms the four scheme historical review is linked, the message still remains: God will bring these kingdoms to an end. This message is presented to an audience in a rhetorical situation where they were confronted by an alien people and their sadistic ruler.

The audience reacted to political events that led to overwhelming profanity and desecration of the temple. In their reaction they followed in opposition to other groups a direction of ".... entpolitisierenden Programmatik ..." (Albertz 1992:671). The author(s) of Daniel wanted to show his/their readers "... dass die eigentliche Auseinandersetzung nicht auf politischem, 


\section{Reviewing history in apocalyptic literature as ideological strategy}

sondern auf religiösen Gebiet ablief" (Albertz 1992:671). Their attitude can be called "an apocalyptic modification of ascesis" (cf Venter 1997:83-88). As their viewpoint expressed in the fourfold kingdom/empire/era historical scheme was that God appoints kings and rejects them, they preferred to wait for the events of the end time to be started from heaven. Using metal symbols and referring with his/their fourfold scheme to successive kingdoms/empires/eras well known by his/their audience the author(s) used the historical review to persuade the hearers that the political trials they experience will come to an end as all empires come to an end in history. It is only God's kingdom that will last forever.

\subsection{Daniel 7}

Daniel 7 has a similar theme as Daniel 2. God's power will prevail all earthly kingdoms and replace them by his eternal sovereignty. The statue of four different materials is represented here as four fearsome beasts. The rock destroying the statue is represented here by one like a son of man who receives an everlasting dominion replacing the domination of the beasts. In both cases revelation is received in the form of a dream. The social and historical circumstances in Daniel 7, however, differ from those in Daniel 2 (cf Collins 1993:323) and the dream is this time interpreted by a heavenly being. Daniel 7 was influenced by the contents of chapter 2 in the conception of a dream vision about four kingdoms. The influence of chapter 2 is, however, only one factor among many others in Daniel 7. Comparatively little of Daniel 7 can be explained by chapter 2 (cf Collins 1984:79).

In Daniel 2 the different materials of the statue were explicitly linked to four different kingdoms (cf Dn 2:39). In Daniel 7 the four beasts are also linked to "four kingdoms that will rise from the earth" (7:17). In Daniel 2 the first kingdom was related to Nebuchadnezzar's reign, while the others were anonymous. In Daniel 7 none of the four kingdoms is linked to any specific historical realm, but the revelation is focused on the fourth kingdom. The deteriorating development from the first to the fourth kingdom in Daniel 2 is reversed in the dynamic description of the beasts in Daniel 7. Each beast is progressively meaner here (cf Miller 1994:197). The fourth beast is the worst. $\mathrm{He}$ is different from the former three and has ten horns with another horn coming up between them speaking boastfully while three of the horns are uprooted.

Although allusiveness (cf Goldingay 1989:148) remains to be part of the historical review, the summary in Daniel 7 is more extensive than the narrative in Daniel 2. Not only is the fourth beast related to a fourth kingdom, but its horns are also explained to be ten successive kings of this kingdom 
followed by a totally different king who subdued three other kings. His boastfulness is described as oppression of the saints of God and his efforts to change the set times and the laws of God's people.

This dream narrative or symbolic dream vision (cf Collins 1993:323) addresses a dramatic situation in which the faithful are oppressed by the tyranny of a rude king. It uses a summary of history presented in the form of four symbolic animals indicating four successive kingdoms and the kings of especially the fourth empire. Traditional mythological figures such as animals that rise from the sea and a heavenly throne are used to review the history. All of this is used to give hope to the persecuted Jews (cf Collins 1993:324). They are assured that the downfall of this hateful king is eminent as all kings before him were destroyed and their power taken away by the Most High.

The animal symbolism used for indicating kingdoms has a mythic background. Redditt (1999:118-119) refers to Delcor's suggestion that the beasts were taken from signs of the Zodiac and Rimbach's idea that they were derived from curse language. Redditt (1999:119) himself is of opinion that the source is the Old Testament itself. Hosea 13:7-8 refers to a panther, a bear, a lion and a wild beast. These animals are changed to have horns and other paraphernalia that changes them beyond recognition.

Again in chapter 7 differences occur between the traditional scholars and those using the Maccabean theory. The first group interprets the four empires as those of Babylon, Medo-Persia, Greece and Rome. The latter considers the four empires to be Babylon, Media, Persia and Greece. For those who accept the Maccabean thesis the portrayal of the last boastful king fits the known information on Antiochus Epiphanes so well, that most scholars agree that the description of the last horn is very probable a reference to Antiochus IV Epiphanes (175-163 BCE) (cf Turner 1962:150). For the traditional school there is no doubt that the fourth kingdom refers to the empire of Rome and the Antichrist. For both schools it means creative inventiveness to make the fourfold scheme fit into known history. While historical background information is supposed to help the exegete in understanding the text his specific historical construction often becomes the key for interpreting the text. Redditt (1999:123) remarks that it is not really necessary to solve the problem of the kingdoms to understand the message of Daniel 7. Although it would have been immensely helpful to know the background and the exact referents of the animal symbols, the main question remains what the hearers/readers of Daniel 7 originally heard and what the purpose of the author(s) was when he/they used the four-kingdom motif as a historic review. 
To try and grasp the intention of the historical review in Daniel 7 it should also be read in the context of the larger structure of Daniel 2-7. The Aramaic narratives display a chiastic structure that indicates that Daniel 7 balances Daniel 2 (cf Redditt 1999:114). Daniel 4-5 forms the nucleus of this structure (cf Boccaccini 2002:176-9). In this centre section the message is that God has absolute sovereignty. He is in supreme control and can grant power to kings, even gentile kings, and also take it away from them. He granted sovereignty to Nebuchadnezzar and his son Belshazzar but is ready to revoke it whenever they show themselves unworthy. Daniel 3 and 6 forms a frame around Daniel 4-5. Here the same story is told with different nuances. Daniel and his three friends are faithful subjects to the foreign kings. When they are forced to show their unwillingness to be unfaithful to their own God they are thrown either into the burning furnace (Dn 3:1-30) or the lion's den (Dn 6:1-28). God intervenes and saves them in both cases. Each time the foreign king has to admit God's superior sovereignty. In the outer frame (Daniel 2 and 7) the end of foreign rule is announced. In both a four part historical review is used. Four kingdoms must pass, represented by either a great statue made of different materials or four beasts. God grants sovereignty to these kingdoms, but only for a restricted time. It is only God's eschatological kingdom which shall never come to pass and will endure forever.

It seems as if it is not the specific kings or kingdoms indicated which are of primary importance, but rather the ideological pattern recognised in history that takes central stage. The image of the four kingdoms touches upon what Hengel called the book's "theology of history" (cf Anderson 1984:10, 11). The author(s) reflected on "der Realismus mit Blick auf irdische Machstrukturen und ihr innerstes Wesen" (Stahl 1994:55), their meaning and the immeasurable harm which these political systems did to people. It is the retreat in the successive kingdoms towards brutality and deceit against God and his people and their final downfall attributed to God that marks history for the author(s). The factual kings and kingdoms symbolised in the historical review merely prove the point of the correctness that the pattern in history is towards decline and obliteration. The dreams and visions of what was to follow were actually a reading of history, a looking back at events from a specific theological perspective (cf Redditt 1999:132) that recognises a pattern in history in terms of God and the progress of human sin. It traces the history of the powers of the world in terms of "God's history" (Helberg 1995:280).

If this is understood in terms of the Maccabean theory, it means that contemporaries from the wisdom groups like Jesus ben Sirach relayed all 
government to God as their source (cf Sirach 10:4, 14). Its more secular vision, however, is that the continuation of the kingdom depends on the ethical quality of the king (cf Sirach 10:7, 12, 13, 18). According to Boccaccini (2002:179-180) a change came with the Maccabean crisis. Universal history now moved to the centre of Jewish thought. In Daniel and the later Enoch material God controls all of history. He decides upon kings and kingdoms. Evil and violence are an integral part of the reign of kings and their kingdoms. Because God is in control of all history, there is a theological pattern to be seen when the history of the world is reviewed. Although kingdoms devaluate in terms of God's criteria or even escalate in violence and cruelty, God brings an end to all of them.

In both Daniel 2 and 7 symbolic historical reviews are therefore used to proclaim God's total sovereignty over kings and kingdoms. The faithful are to look at the violence and trials they experience from this perspective. Whatever afflictions or political troubles there are, these are to be viewed on the scale of God's development of history towards its final consummation when all will recognise his eternal kingdom. They do not know precisely where they are on this historical line. Like Moses they can only stand on the brink of this final event (cf Fewell 1991:135). The final kingdom is elusive and they can only hold fast to their expectation. They can recognise from what they undergo that it must be near the end of the pattern. They can only ask: when will the end come? But it must be left to God to bring the end himself.

\section{HISTORICAL REVIEWS IN ENOCH}

\subsection{The Apocalypse of the Weeks (1 Enoch 93:1-10; 91:11-17)}

The fifth book in Ethiopic Enoch is the Epistle of Enoch (1 Enoch 92-105). It is a lengthy document comprising of many small units. The compilation imitates the genre of an epistle. It pretends to be a letter to Enoch's children and his spiritual descendants. Enoch urges them to stand firm while they wait for the eventual judgment. One of the units found in the Epistle is called "The Apocalypse of Weeks" (1 Enoch 93:1-10).

The Apocalypse can be described as a "revelation report" (Collins 1984:10). Along with the Animal Vision (1 Enoch 89:59-90:19) VanderKam (1984b:141) calls this "apocalypses with historical surveys in the form of vaticinia ex eventu." The contents of the revelation that Enoch saw in the heavenly tablets ${ }^{1}$ is reported in a heavenly vision. As in Daniel 8, 10-12, 1

\footnotetext{
${ }^{1}$ VanderKam (1984b:151) remarks that heavenly tablets are mentioned frequently in the literature of the second-temple period and were "regarded as sources of data about the course of history and particularly about the end time." Heavenly tablets figure in 1 Enoch 81:12, 93:2, 103:2 and 106:19.
} 
Enoch 85-90 and 2 Baruch 56-71, the history of the world is tracked down from a point in the past to the time of the author(s). In this case it is the history from creation to the last days. This global history is schematised in ten periods called "weeks." It continues a firmly established apocalyptic tradition which structures the history using the numbers seven and ten. The division of the history in ten periods is also found in Sibylline Oracles 1, 2 and 4. In 4Q180 and 181 the ten ages from Noah to Abraham are divided into ten weeks. In the Ethiopic version the contents of the first seven weeks are found in 1 Enoch 93:1-0. All of the ten week cycle is found in the Aramaic mid-first century BCE Qumran document 4QEn ${ }^{g}{ }^{2}$ In the Ethiopic version the contents of the last three weeks were moved to 1 Enoch 91:11-17.

Rather than speculating on the meaning of these weeks or trying to calculate them in terms of known time, for instance seventy year-cycles, the question should be asked why the author(s) used this schema for the history. One possible answer is that he/they saw in history the neatness of God's creation. Being aware of current learned trends to organise history in periods (cf VanderKam 1984b:156-9) he/they tried to characterise the world in which he/they lived. Another probable reason for the schematisation is to contrast righteousness and evil. All of history is seen in terms of human beings either being righteous and chosen, or being wicked and perform violence. People's deeds are either righteousness or deceit and perversion. From the beginning history had a pattern of evil opposing justice. The development of history illustrates that human deeds, both good and evil, are subjected to inevitable divine judgment. In terms of a set of ten weeks, especially from the seventh week onwards, the judgment is linked to an inevitable final judgment (cf Nickelsburg 2001:419). The eschatological hope of the annihilation of sin and eternal vindication of righteousness is propagated here by using a historical review of humanity's history. This validates the expectation of a change as God's predetermined decision revealed to Enoch in the heavenly tablets. This chronological review is given in a more extended form in the Animal Vision.

\subsection{The Animal Vision (1 Enoch 89:59-90:19)}

The fourth book of Enoch is the Book of Dream Visions (1 Enoch 83-90). In this book Enoch recounts to his son Methusaleh two dream visions he had before he married. In these pseudonymous dream visions "every deed of humanity was shown to me in its order" (1 Enoch 90:41) recounting a sequence of historical events up to the eschaton.

In the first dream vision (1 Enoch 83-84) he foresees the destruction of the world in the deluge. In this "dream vision report" (cf Reid 1989:57f) three

\footnotetext{
${ }^{2}$ For a comparison between the Ethiopic and Qumran rendition see VanderKam (1984a:513518).
} 
traditions are found: the fall of the angels, call of Enoch, and intercession. This section is intended to legitimate the teachings of Enoch that follows in 85-90. In the second dream vision, sometimes called the "Animal Apocalypse" (1 Enoch 85:1-90:42) the history of the world is presented from the creation of the earth to the time of the judgment and up to a second renewal symbolised by animals. Three literary types occur in this vision: historicized fable/ theriomorphic historical allegory/ "zoomorphic historical apocalypse" (Tite 2001:109), apocalyptic timetable, and report of judgment. Human history is divided into three major eras in this second dream vision:

- $\quad$ From the creation to the flood (85:3-89:8);

- $\quad$ From the renewal of the creation to the great judgment (89:9-90:27);

- $\quad$ Second renewal unto a new future (90:28-38) (cf Nickelsburg 2001:354).

A similar pattern of history is used for the first two eras. Each time it moves from creative beginnings via disintegration as result of sin to termination by divine judgement. The third era (second renewal) represents a return to the primordial beginning. The overarching plot of this second vision is the story of humanity with its ongoing presence of sin in the form of either violence or apostasy. The violence hails exclusively from the gentiles. They are therefore depicted as predatory and scavenging wild animals and birds. Israel on the other hand is symbolised by bulls and cows and sheep. They are not guilty of violence but always the victims of the violence of the nations. This is their punishment for straying from God's will and apostatising from the divinely revealed cult.

Different from the first dream vision this second dream vision "contains an elaborate metaphorical drama cast unto the cosmic realm" (Tite 2001:109). When compared to the visions in Daniel 2 and 7 a much broader historical scope appears in this second vision. ${ }^{3}$ The periodisation of history into a sequence of empires in the two Daniel visions is used again, but complemented here with a review of Israel's history a lá the biblical traditions and an overview of all of human history. The history of humanity at the beginning and end of the second vision (1 Enoch 85:1-90:42) forms an inclusio for the history of Israel. In this inclusio two "histories" are found: a traditional biblical history of Israel in 1 Enoch 85:3-89:58 and the periodisation of their

\footnotetext{
${ }^{3}$ By selecting Enoch as the person who receives the revelation the author(s) could broaden their scope from the ancient time when Enoch lived to their own time, compared to the author(s) of Daniel who were restricted to the time between the sixth century when Daniel was supposed to live and their own time (cf VanderKam 1984b:153-4).
} 
history in 1 Enoch 89:59-90:19. This last section is usually called the "Animal Vision". 4

\subsubsection{The traditional biblical history (1 Enoch 85:3-89:58)}

This biblically based history uses theriomorphic allegory to present Israel's history. Although it is allegorical all of this history is based on earthly events moving exclusively along a temporal plane (cf Tite 2001:110). The history follows the same order as the narrative books in the Bible. Major points of correspondence can be indicated with these, like e.g. creation and fall, flood, Abraham, exodus et cetera. ${ }^{5}$ According to Nickelsburg (2001:359) the traditional material from the Bible is restructured according to a "scheme of sin, punishment, repentance, and restoration." Although this scheme has much in common with the Deuteronomistic history, the linear historical view in Deuteronomy is replaced by an eschatological dichotomy where the final restoration is interpreted as a reversion back to creation and a restoration of the integrity of the whole human race (cf Nickelsburg 2001:359, 398-400).

In contemporary apocalyptic literature such as Jubilees 1:7-29 and 23:11-32 the same "Deuteronomistic Patterning" (Endres 1987:53) is used for the history of Israel. The scheme of transgression (Jubilees 23:16-21), punishment (Jubilees 23:22-25), repentance (Jubilees 23:26) and salvation (Jubilees 23:27-31) is used. Jubilees as "Rewritten Bible" (VanderKam 2001:93-4, 137-8) presents Genesis to Exodus 24 as revelation given to Moses regarding the circumstances of the author of Jubilees during the second century BCE (cf Venter 2003a:981-8). His application of the scheme is primarily aimed at cultic and nationalistic reform of the community of Judah. It is not as universal in scope as that of the Book of the Dream Visions.

In the Cairo Damascus Document Grossman (2002:88) saw three types of historical accounts used in the document: linear narratives, accounts with a more static view of human experience, and accounts which understand human experience as a cyclical repetition of the same basic actions. The author(s) of CD used historical reviews in I:3-12, II:14-IV:2, IV:12-V:16V:15b$\mathrm{VI}: 4$ to conceptualise the identity of his/their group, applied the traditional national sequential pattern of sin-punishment-repentance-salvation to his/their dualistic view that God simultaneously deals with the rejected as well as the elected, advanced his/their theology on the "remnant", warn those newly initiated in the group to observe God's laws and propagate the superiority of his/their form of Judaism (cf Venter 2003b:618-621).

\footnotetext{
${ }^{4}$ First Enoch 85:1-90:42 is called the "Animal Apocalypse" and 1 Enoch 89:59-90:19 the "Animal Vision."

${ }^{5}$ Cf Nickelsburg (2001:358) for an extensive list.
} 
The similarities with the Jubilee group and the group responsible for the Damascus Document with regard to the use of traditional history patterns from the Bible can indicate similar reform movements in Judah during the second century BCE. The person/group from the Enochic movement responsible for the Book of the Dream Visions, however, used the traditional history patterns in a unique way. In Nickelsburg's (2001:364-367) translation of 1 Enoch 85:386:58 he uses the following headings: Adam and Eve and their children (85:310); The fall of the watchers and the violence of the giants (86:1-6); Divine judgment (87:1-88:3); Noah and the flood (89:1-8); From the disembarkation to the exodus (89:9-27); From the exodus to Moses' death (89:28-38); From the entrance into the land to the building of the temple (89:39-50); The apostasy of the two kingdoms (89:51-58). 1 Enoch 85:3-10 covers the events described in Genesis 2-5. 1 Enoch 86:1-87:1 is an elaborate elucidation of Genesis 6:1-4. 1 Enoch 89:1-8 is a paraphrase of Genesis 6:5-9:19. 1 Enoch 89:10-12 summarises Genesis 10:1-37:1 in a very brief section on the transition from Noah's death to the beginning of Israel. The history from the selling of Joseph to the death of Moses (Gn 37-Dt 34) is represented in 1 Enoch 89:13-38, the main part of the second vision, which corresponds mostly with the narrative sections of the book of Exodus. The book of Joshua, the book of Judges, the rise of Samuel and the first three kings of Israel are reflected in 1 Enoch 89:39-40,41a, 41b and 42-50 respectively. 1 Enoch 89:51-58 depicts the sharp decline of Israel following 1 Kings 12- 2 Kings 25. The biblical history is expanded by traditional Enochic viewpoints (as mainly found in 1 Enoch 6-8) and contemporary haggadic extensions. It is also drastically shortened when it comes to issues not serving the author(s)'s viewpoint on the history of Israel (for instance the reforms of Josiah). Nickelsburg (2001:381) points out three characteristics of the second dream's representation of the biblical history:

- $\quad$ For most of its history the nation has violated God's revealed law, specifically with respect to cultic matters.

- Israel's victimization by the gentiles is divine punishment for sinning against God's revealed law.

- $\quad$ The acceptance of a new revelation will bring about Israel's final and permanent deliverance from their enemies.

The most obvious change to the biblical tradition is the deletion of all personal names and geographical identification. Spatial specifications are exchanged for generic-symbolic names like the earth, the heaven, a tower, an abyss, a high roof and seven sluices, a lofty chamber, a river of much water, a swamp 
of much waters, the summit of a rock, a desert et cetera. Personal names are replaced with animal categories. The actors in events are bulls, cows and sheep that are ravaged by different types of wild animals. According to Tite (2001:110) this change to allegory could have been intended to affect the recipients of the vision in two ways: the dehumanisation of the opponents as monstrous beasts encouraging a holy war against them, and reinforcing the insider status of the recipients by presenting the events as coded allegories which only they could understand. Changing the history into an allegory of contrasting animals (bulls-cows/sheep against wild beasts) could have been also a technique to promote cult purity among the insider recipient group. ${ }^{6}$ The author(s) also depict the "sheep" according to visual ability as either being blind, dim sighted or with eyes opened. The history of Israel shows a pattern of dichotomy between good and evil, pure and impure, being faithful and going astray. The motif is found in all of Israel's history that people move from the one to the other. To present history in this way in this section of the vision is a technique to maintain community cohesion and warn against the severe consequences for those who go astray (cf Tite 2001:110-111).

In summary the biblical based historical review in 1 Enoch 85:3-89:58 advocates the view of the author(s) that all of Israel's history is marked by cultic misdemeanour and oppression by other people as God's punishment for Israel's endless transgression. The review also aims at advancing group cohesion against the violence presented by outsider groups.

\subsubsection{The Animal Vision (1 Enoch 89:59-90:19)}

The depicting of Israel as sheep ravaged by wild animals is continued in this second résumé of Israel's history. Compared to the narrative in 1 Enoch 85:389:58, however, several changes occur. Firstly, the space used in the narrative is extended into both earthly and heavenly space. In the previous narrative everything happens on earth. God, however, abandons the sheep, their house and their tower (1 Enoch 89: 54, 55, 56, 58). He withdraws to heaven and although he sees his people on earth devoured by the wild animals he becomes silent. In the summary of 1 Enoch 89:59-90:19 he is in heaven summoning people and angels to his courtroom. The angelic scribe appointed by him has to write down in a book what happens on earth and to report it to God in heaven.

New actors are also introduced in this narrative. God appoints seventy shepherds and their subordinates to pasture the sheep. They may destroy some of the sheep according to their discretion. God also summoned an

\footnotetext{
${ }^{6}$ See Tite's (2001:110) discussion of the transformation of known biblical figures as examples to advance purity among the insider group.
} 
angelic being to monitor these shepherds, as he was afraid that they might destroy more sheep than he had commanded them. These shepherds, however, become the criterion for all events. God has withdrawn to heaven and everything happening with the sheep is now left to the decisions of these shepherds. Their acts recorded in the angel's book will decide God's judgement in the end. ${ }^{7}$

Not only the type of events occurring, but also the time of events is henceforth described in terms of the specific shepherds who act in Israel. Each shepherd pastures "in his time" (1 Enoch 89:65). This time is arranged according to a specific group of shepherds acting in a certain time. The narration refers to the administration of the first twelve shepherds in 1 Enoch 89:72a, the pasturing of thirty-five shepherds in 1 Enoch $90: 1$, the time of twenty three shepherds adding up to fifty eight in 1 Enoch 90:5 and of the last twelve shepherds in 1 Enoch 90:17. Nickelsburg (2001:387-388) interprets this division as indication of four eras. In the headings of his translation he links each group of shepherds to a known historical period: the twelve shepherds are linked to the time up to exile (89:65-72a); the twenty-three shepherds to the time from the return from exile to Alexander (89:72b-90:1); the era of the twenty-three shepherds to the period from Alexander to the second century BCE (90:2-5); and the twelve shepherds who act in the time of the end (90:619).

We are therefore once more dealing with a chronological scheme, this time based on the acts of these "shepherds". The history of Israel is told here in terms of figures to whom God delivered his sheep to destroy them. They act out their role by delivering the sheep to the wild beasts and birds of prey while the angelic being monitors them and writes down how they officiate their commission. As leaders of the sheep the common biblical metaphor for Israel's leaders is used to call them "shepherds." Based on ideas found in Ezekiel 34 and Zechariah 11:15-17 the author(s) identified these shepherds as angels who have been summoned to heaven to receive their task from God.

Nickelsburg (2001:391-393) does not try to identify these seventy shepherds as personages but understands them as indicating successive periods of time in Israel's history. The number seventy is a chronological indication in Jeremiah 25:11-12 $2^{8}$ and 29:10 of the time that the land would

\footnotetext{
${ }^{7}$ Tite finds a deterministic theme in this section which emphasis the controlling hand of God. Tite (2001:112), however, remarks that "this determinism is not imposed upon the fate of humankind." The review is rather based on the shepherds and the report of their acts which will determine God's decision, although he knows beforehand what it will be.

${ }^{8}$ VanderKam (1984b:165-167) sees in the use of the pastoral symbols and the number 70 the enormous importance that the author(s) attached to the prophecy of Jeremiah to understand the exile.
} 
remain desolate after Nebuchadnezzar of Babylon destroyed Jerusalem. In Nickelburg's view the angel Gabriel in Daniel 9:24 interpreted this seventy years of Jeremiah as seventy weeks of years that are necessary to put an end to $\sin$. This is the time required to eliminate the consequences of the sin that caused the exile (sic!), not as traditionally understood as the time which has to pass since the beginning of the exile (cf Nickelsburg 2001:392). According to Nickelsburg's theory the Animal Vision identifies Manasseh's sin as the cause of the exile. The seventy angelic periods began with Manasseh's reign. Nickelsburg (cf 2001:392-393) understands each shepherd as an indication of seven years. The seventy periods would therefore indicate the 490 years between Manasseh's reign (687-642 BCE) and 181/171 BCE. Although the four periods of the vision might coincide with Israel's submission to four empires or kingdoms (Assyria-Babylonia-Persian-Macedonia, or Babylonia-PersianPtolemeans-Seleucids) Nickelsburg prefers to start the angelic period with Manasseh and link the periods in the vision to the years calculated from Manasseh to the time of the authors. If the Animal Vision does indeed identify Manasseh's sin as the cause of the exile "then it would appear that Daniel 7 and the Animal Vision reflect variations of a common tradition about the exilic and postexilic periods" (Nickelsburg 2001:392).

Whether one agrees with Nickelburg's theory that each shepherd represents seven years or not, the text itself presents the events in terms of shepherds who acts each in his respective time (1 Enoch 89:65,68; 90:1). Against Nickelburg's effort to divide events into seventy times seven units/years it should be remarked that the narrative itself does not deal with these shepherds or epochs separately, but arranges them into four successive groups. The events are narrated in terms of the (first twelve?) shepherds pasturing for twelve hours ( 1 Enoch $89: 72 a$ ), the time of the thirty five ${ }^{9}$ shepherds (1 Enoch 90:1), the time that twenty-three shepherds had been pasturing (1 Enoch 90:5), the destruction that those last twelve shepherds worked (1 Enoch 90:17). Rather than speculating on how many years each separate shepherd represents it seems better to think of this time in terms of four periods. This would rather agree with a common tradition also found in the four era schemes found in Daniel 2 and 7.

To understand the dream vision's specific use of this common tradition of a four-era chronology I want to concentrate on the fourth era of the last twelve shepherds. The events reach a climactic eschatological finale. Events take a sudden change. A militant person appears on the scene depicted as a ram with a horn. The monitoring angel helps him against the onslaught of the different wild animals. The Lord intervenes and judges all the beasts and birds

${ }^{9}$ Cf Nickelsburg (2001:389) for the reading "thirty seven". 
of heaven. He grants the sheep the opportunity to take revenge on all the beasts and birds of heaven who then flee before them. It is widely recognised that this depiction of the militant ram with the horn in 90:9b-16 refers to the Maccabean war (cf Nickelsburg 2001:361; Albertz 1992:666; Tite 2001:113). The seeing/not seeing motif continued from the previous traditional biblical history (1 Enoch 85:3-89:58) is used with even greater intensity in this Animal Vision and intensifies the depth of the horror that the sheep face during this fourth era (cf Tite 2001:112, 113). It reflects a socio-political conflict that remarkably fits the known circumstances of the Maccabean revolt. The military activity of the Maccabees are hailed here as the events which changed the fate of the people. The Maccabees were sent by God to start the great final war. The Trägerkreis of the apocalypse was very much inclined towards the viewpoint of these Maccabees. The author(s) even joint forces with the Maccabees, and developed “.... eine martialische apokalyptische Propaganda ..." (Albertz 1992:666).

First Enoch 90:6-7 articulates the idea of the author(s)/group that they are the recipients of a revelation in which they experience a divinely prompted religious awakening. It is their purpose with these writings to propagate this revelation and try to persuade others of it. This revelation is either a disclosure of a new torah or new insight into the old existing torah. It is closely related to the sanctuary and the cult (cf Nickelsburg 2001:361). However, they are of persuasion that this revelation started a chain of events that will lead to the final judgment. God will finally reward and punish his people's torah-related conduct. The violence done to the sheep will peak towards the end of Israel's history. This will happen in a time of military action by a figure depicted as a ram with a horn. If this indeed refers to the acts of Judeas Maccabeus, it means that the author(s)/group interpret(s) current events according to their ideology and claims to understand the eschatological character of their time and to have insights into the hidden divine activity in the heavenly realm that was about to resolve injustice and eradicate evil finally on earth (cf Nickelsburg 2001:357).

They probably welcomed the Maccabean war because they were unsuccessful to persuade others of their ideology (cf Albertz 1992:666 ".... die bisherige Erfolglosigkeit ihrer theologischen Aufklärungsarbeit"). Another possibility is that they simply recognised in the contemporary events the opportune moment to propagate their viewpoint. Whichever one is true, the positive evaluation of the military person's activity and connecting of it to the help of the angelic being and God's final intervention indicates clearly the liberating meaning they linked to these historical events. By interpreting these political-military events as the zenith of Israel's history they made a change to the original Urzeit-Endzeit typology. As Uhlig (1984:492) says, they gave “.... 


\section{Reviewing history in apocalyptic literature as ideological strategy}

einen radikale Geschichtsdeutung" to the present-day events as "Gerichtsoder doch Zorneszeit" which leads to the new dispensation of God's kingdom. The time of the seventy shepherds as well as the oppression of the sheep has come to a final end. A radical change in history is going to take place.

In their view history was always characterised by violence and oppression. All through its history Israel was the victim of unjust violence. Although Israel was punished for his apostasy (the shepherds were allowed to punish them), the foreign kings went beyond the limits set by God by oppressing Israel. The "seventy times" have now come to an end and these kings are going to be punished for what they did. As victim of superfluous oppression Israel had the right to overpower their oppressors as it happened in the book of Esther and as it occurred in the Maccabean revolt in their days. In this way the manner in which the history is presented here becomes a technique to appraise the political-military events of the Maccabees and even propagate their actions as eschatological liberating events (cf Albertz 1992:667).

The legitimation and even participation of these military actions were advanced by also linking the history of Israel to universal history. As Rowland puts it: "The readers of the apocalypses are permitted to see that the experiences of the present must be related to the totality of human history, whose course is entirely directed by God" (Rowland 1982:143). The second dream vision (1 Enoch 85:1-90:42) includes the traditional history of Israel (1 Enoch 85:3-89:58) as well as the era of the seventy shepherds appointed to rule Israel (1 Enoch 89:59-90:19). This history moved in ever widening circles to include the wild beasts of the world as well. The final section of the judgment and the new age (1 Enoch 90:20-42) ends by summing up the two dreams as "every deed of humanity was shown to me in order"(1 Enoch 90:41). The violence and oppression is not only restricted to Israel as God's punishment for their blindness and unwillingness to obey his torah, but also includes the entire humanity in whose history excessive violence occurs against Israel and is castigated by God when he allows Israel to take revenge. Israel's history therefore is seen and evaluated within a universal framework.

When the Animal Apocalypse is compared to the Hebrew Daniel the purpose of the revelation of the author(s) of Enoch becomes clear. The author(s) of the Animal Apocalypse, rather different from the Hebrew Daniel, do(es) not refer to the profanation of the temple by Antiochus. In Daniel profanation of the cult is caused by external factors which brought the evening and morning sacrifices to an end. The animal with the horn in Daniel is an indication of a foreign power (Dn 7:8,24-25; 8:9-12, 23-25), while in Enoch $(90: 9,12-13)$ he is one of the sheep liberating the other. Daniel's scope in 
chapters 2 and 7 is restricted to four kingdoms on earth. In Enoch all of humanity is included. Both end with the events of their day, Daniel with restoration of the cult, Enoch with revenge on all enemies of Israel. While the Animal Vision was probably intended to rewrite the Apocalypse of Weeks and to clarify its timetable to make clear that the end will come in the near future, both see the end of the four major periods of history in accordance with a fourkingdom scene, documented in Daniel 2 and 7 and indicated, according to Nickelsburg's (2001:392-393) theory, as 490 years after Manasseh's sin in accord with the tradition that is attested later in Daniel 9. Daniel's theriomorphic symbolism is expanded in Enoch into a full-blown allegory in which the individual species represent specific nations (cf Nickelsburg 2001:357). While Daniel explains his animal symbols, those of Enoch are intended to be selfexplicatory.

From this comparison it becomes clear that the author(s) of the Dream Vision does not intend to regain and rededicate the temple, but to act in sympathy with the militant political movement for nationalistic religious change. According to Albertz' (1992:668) theory his/their view on Israel's violent history can be seen “... als engagierte Stellungsnahme des politisch aktiven Flügels der Chasidim innerhalb der makkabaïschen Aufstandsbewegung ...". Whether he/they could be seen as part of the Chasidim depends one one's definition of whom the Chasidim were. The Enochic author(s) was/were in union with Ezekiel 34 to criticise leaders of the Jewish community for abusing their position. According to Reid's (1989:65) theory, we are dealing with a group who used anti-Hellenistic propaganda against all Hellenistic orientated leaders without being against either Ptolemies or Seleucids per se. Militancy is a significant component of their ideology (cf Nickelsburg 2001:362) and they use their historic reconstruction of Israel to legitimise the actions of the Maccabees, even participating in their liberation war.

\section{IN CONCLUSION}

The different employments of historical summaries in Daniel and Enoch reflect their basic difference as non-resistant apocalypticism understanding social change as exclusively God's work against activistic apocalypticism which acknowledges that social change must originate with God, but must be advanced by military action (cf Reid 1989:133; Venter 1997:88-90). The author(s) probably belonged to an Enochic apocalyptic movement of the third century BCE (cf Venter 2003c:229-230) who expressed their views on the chaotic influence of evil in their time inter alia by reviews of Israel's history. They propagated their viewpoint that all evil will come to an end by military 


\section{Reviewing history in apocalyptic literature as ideological strategy}

action in which the righteous is to play a role. The Danielic author(s) belonged to a movement that propagated an "apocalyptic modification of ascesis" (cf Venter 1997:83-88). They used their reviews of history to indicate the pattern that God himself intervenes and brings kingdoms to an end. They urge their followers to be tolerant and keep themselves ready for the final event when God will break into history with his eternal kingdom.

\section{Works consulted}

Albertz, R 1992. Religionsgeschichte Israels in alttestamentlicher Zeit, Teil 2: Vom Exil bis zu den Makkabäern. Göttingen: Vandenhoeck \& Ruprecht.

Anderson, R A 1984. Daniel. Grand Rapids, MI: Eerdmans. (International Theological Commentary.)

Baldwin, J G1978. Daniel. Leicester: Inter-Varsity Press.

Baumgarten, A I 2000. The perception of the past in the Damascus document, in Baumgarten J M, Chazon E G \& Pinnick A, The Damascus Document: A centennial of discovery, 1-15. Proceedings of the Third International Symposium of the Orion Center for the Study of the Dead Sea Scrolls and Associated Literature 4-8 February, 1998. Leiden: Brill.

Boccaccini, G 2002. Roots of Rabbinic Judaism: An intellectual history, from Ezekiel to Daniel. Grand Rapids, MI: Eerdmans.

Breytenbach, A P B 1997. Meesternarratiewe, kontranarratiewe en kanonisering: 'n Perspektief op sommige profetiese geskrifte. HTS 53(4),1161-1186.

Collins, J J 1984. Daniel with an introduction to apocalyptic literature. The forms of the Old Testament literature XX. Grand Rapids, MI: Eerdmans.

Collins J J 1993. A commentary on the book of Daniel. Minneapolis, MN: Fortress. (Hermeneia.)

Endres, J C1987. Biblical Interpretation in the Book of Jubilees. Washington: The Catholic Biblical Association of America. (The Catholic Biblical Quarterly Monograph Series 18.)

Fewell, D N1991. Circle of sovereignty: Plotting politics in the book of Daniel. Nashville, TN: Abingdon Press

Goldingay, J 1989. Daniel. Dallas, TX: Word Books. (World Books Commentary.)

Grabbe, L 1992. Judaism from Cyrus to Hadrian, vol 1: The Persian and Greek Periods. Minneapolis, MN: Fortress Press.

Grossman, M L 2002. Reading for history in the Damascus Document: $A$ methodological method. Leiden: Brill.

Hartman, L F \& Di Lella, A A 1978. The Book of Daniel. New York: Doubleday. (Anchor Bible.)

Helberg, J L 1995. The determination of history according to the book of Daniel. ZAW 107(2), 273-287.

Jeismann, K-E 1985. Geschichte als Horizont der Gegenwart: über der Zusammenhang von Vergangenheits Deutung, gegenwartsverständnis und Zukunftperspektive. Paderborn: Schöningh.

Koch, K 1980. Das Buch Daniel. Erträge der Forschung. Darmstadt: Wissenschaftliche Buchgesellscaft.

LaCocque, A 1979. The book of Daniel. London: SPCK. 
Miller, S R 1994. Daniel. Nashville, TN: Broadman \& Holman Publishers. (The New American Commentary.)

Nickelsburg, G W E 2001. 1 Enoch 1: A commentary on the Book of 1 Enoch Chapters 1-36; 81-108. Minneapolis, MN: Fortress Press.

Redditt, P L 1999. Daniel: Based on the New Revised Standard Version. Sheffield: Sheffield Academic Press. (New Century Bible Commentary.)

Reid, S B 1989. Enoch and Daniel: A form critical and sociological study of the historical apocalypses. Berkeley, CA: Bibal Press.

Rowland, C 1982. The open heaven: A study of apocalyptic in Judaism and early Christianity. London: SPCK

Stahl, R 1994 Von Weltengagement zu Weltüberwindung: Theologische Positionen im Danielbuch. Kampen: Kok Pharos.

Tite, P L 2001. Textual and redactional aspects of the Book of Dreams (1 Enoch 8390). BTB 31(3), 106-120.

Turner, N 1962. s v Antiochus. The Interpreter's Dictionary of the Bible, vol 1, 149152. New York: Abingdon.

Uhlig, S 1984. Apokalypsen: Das äthiopische Henochbuch: Jüdische Schriften aus hellenistisch-römische Zeit, Band V. Lieferung 6. Gütersloher Verlaghaus Gerd Mohn.

VanderKam, J C 1984a. Studies in the apocalypse of weeks (1 Enoch 93:1-10; 91:11-17). CBQ 46, 511-523.

VanderKam, J C 1984b. Enoch and the growth of an apocalyptic tradition. Washington, DC: Catholic Biblical Association. (The Catholic Biblical Quarterly Monograph Series 16.)

VanderKam, J C 2001. An introduction to early Judaism. Grand Rapids, MI: Eerdmans.

Van Deventer, H J M 2002. Die boek Daniël: 'n Retories-kritiese lesing van die Aramese gedeeltes. DD-proefskrif, Potchefstroomse Universiteit vir Christelike Hoër Onderwys, Potchefstroom.

Venter, P M 1993. The function of poetic speech in the narrative in Daniel 2. HTS 49(4), 1009-1020.

Venter, P M 1997. Daniel and Enoch: Two different reactions. HTS 53(1\&2), 68-91.

Venter, P M 2003a. Intertekstuele aanduidings van die wêreld van die boek Jubileë. HTS 59(3), 957-989.

Venter, P M 2003b. Historical review in the Damascus Document. Verbum et Ecclesia. 24(2), 598-622.

Venter, P M 2003c. Spatiality in Enoch's journeys (1 Enoch 12-36), in F G Martinez (ed), Wisdom and apocalypticism in the Dead Sea Scrolls and in the biblical tradition, 211-230. Leuven: Peeters-Leuven University Press. (Bibliotheca Ephemeridum Theologicae Lovaniensum CLXVIII.) 